\title{
Parent Satisfaction with the Child Health Centres 0-5 years old in Norway: A Cross-Sectional Study
}

\begin{abstract}
In Norway, all children are entitled to receive regular health controls. Child health centres 0-5 years old (CHC) provide these check-ups and are one of many health services that Norwegian municipalities have to offer. The aim of this study is to examine parents' satisfaction with the CHC, and to identify predictors for the overall evaluation of the service.

The sample comprised 1654 parents who visited the CHC with their children. A hierarchical multiple regression analysis was conducted to predict the overall evaluation with the service with four user satisfaction scales (i.e., User participation, Public health nurse, Accessibility, and Information). The STROBE checklist was applied.
\end{abstract}

Most users were satisfied with the service (95\%) and with the help they received from it (91\%). All four user satisfaction scales were significant in the prediction of the overall evaluation with the service.

Users of the CHC seem to be very satisfied with the service, especially with the public health nurse.

Key words: child health care, user survey, satisfaction, service quality 


\section{Introduction}

Child health centres 0-5 years old (CHC) are low-threshold, free of charge, and universal health services for children and their families that every municipality in Norway has to offer to their inhabitants ${ }^{1}$. The purpose of the service is to carry out health promoting and preventive work for children aged 0-5 years and their parents or caregivers, including pregnant women. The aim of the service is to contribute to promoting mental- and physical health, good social conditions and it aims at preventing social inequalities, illness, and injuries. Another task of this service is to contribute to the prevention and detection of abuse and neglect ${ }^{2}$.

According to national guidelines, each child health centre $0-5$ years old offers 14 age-specific consultations from the time the child is born until it is 5 years old ${ }^{3}$. There are for example instructions about which health examinations and vaccines that must be carried out at each consultation, and which health information and guidance that should be given to the parents or caregivers. Physical examinations are conducted to see whether the child is developing as expected and include for example the measurement of the child's weight and height but also sight and hearing are tested in addition to the language development and oral examinations. Furthermore, public health nurses should provide guidance within topics such as diet, psychomotor development, and tobacco and alcohol use. In Norway, public health nurses are nurses with an additional education in health-promoting and disease-prevention aimed at children and their families. Some of their tasks include conducting physical examinations and giving advices regarding health and upbringing to children and their families ${ }^{4}$. As the parents' or caregivers' mental health can affect their ability to care for the child, they will be asked about their mental health. In addition to the public health nurse who usually conducts the consultations, a medical doctor at the health centre examines the child's physical health at six weeks, six months, one year, and two years ${ }^{3}$. 
$\mathrm{CHC}$ are one of several universal health services every municipality in Norway has to offer for the follow-up of children's health and development from before the child is born until it turns 20 years old ${ }^{1}$. This health promoting and preventive work also includes working with the child's family to ensure the best home environment that facilitates healthy development. The other services include maternity care, school health service, and health centres for young people up to the age of 20 years. In addition to the universal health services for children and their families, Norwegian municipalities have to offer educational-psychological services for children with special needs in kindergartens and schools ${ }^{5,6}$ and child protection services ${ }^{7}$.

While the above mentioned municipal health services are required by law, municipalities can decide themselves how they want to organize these services. One model for organizing the services is the Family House model, which has a strong focus on interdisciplinary collaboration between services and occupational groups. The most common services included in the Family House model are the health center, maternity care, educational-psychological services, and child welfare services but the composition of services can vary from municipality to municipality ${ }^{8}$. The model can be described as house consisting of a foundation and three floors. The foundation is based on professional competence. The first floor consists of universal, health-promoting- and preventive health services such as the open kindergarten, the health center, and the maternity care. Families who are at increased risk will be discovered here and referred to the second or third floor. The second floor is a selective offer for families with a slightly increased risk, where they can for example participate at group offers for young mothers or where they receive closer follow-ups of children with mental sick parents. The families who are at high risk, show early symptoms or need for follow-up are referred to the third floor, where they will get an indicated offer based on their needs ${ }^{8}$. 
Like the other municipal health services, the CHC are required to systematically work with improving their service quality ${ }^{9,10}$. In accordance to the Norwegian Directorate of Health "Services of good quality are effective, safe and secure, involve users and give them influence, are coordinated and characterized by continuity, utilize resources in a good way, are available and distributed fairly” ${ }^{9}$. Service quality can be assessed through quality indicators, self- or third-party evaluations, supervision or inspections, and through user satisfaction surveys ${ }^{11}$. The latter one is a useful tool to assess, to some extent, the effectiveness of service and the user's experiences of their involvement and influence, coordination and continuity, and availability of services. From the user's perspective, service quality is the extent to which their expectations match the actual received service ${ }^{12}$. User's expectations include the "result of the treatment, absence of unwanted events or injuries, waiting time, geographical proximity to the services, options, information, possibility of participation, the behavior of the health and care personnel, other matters related to service” ${ }^{11}$. While some municipalities conduct user satisfaction surveys locally in their CHC, there is, to the best of our knowledge, no research published. The lack of research in this field documents the need for conducting the current study, especially because of the potential importance of this topic as indicated by related studies ${ }^{13}$. While two studies found a relationship between parental satisfaction and treatment outcome in a child and adolescent mental health service ${ }^{14}$ and in a child psychiatric hospital ${ }^{15}$, another study did not find such a relationship in children's mental health clinics ${ }^{16}$. A review writes "Patient satisfaction with hospital services is one of the most important indicators of effectiveness and quality of hospital services” (p. 1460) ${ }^{17}$. Similarly, a study conducted in Mexico found a relationship between patient satisfaction and service quality ${ }^{18}$. Another study found that patients are more satisfied with the nursing care than with the information they were given ${ }^{19}$. The findings from these studies may be less relevant to our target group as they include adult patients and not 
parents of children from the general population. A user satisfaction study of caregivers who visited open kindergartens in eleven municipalities in Norway that is part of the current study, found that the physical environment, the staff at the open kindergarten, and the benefits for the child and the caregivers at the open kindergarten, were significant predictors for the overall satisfaction with the service ${ }^{20}$. These findings are relevant for the current study since both the CHC and open kindergartens are low-threshold universal services with overlapping user groups.

\section{Study Aim}

The aim of this study was to examine parent or caregiver satisfaction with the CHC in Norwegian municipalities. Another aim of the study was to identify predictors of the overall evaluation with the CHC.

\section{Method}

The current study uses cross-sectional data and is based on questionnaires that were filled out by 1654 users of 46 participating CHC in 27 municipalities in Norway. The STROBE checklist for cross-sectional studies was followed ${ }^{21}$.

\section{Participants and Procedure}

The current study is part of a larger study called "Collaboration and service quality in municipal services for children, adolescents, and their families in Norwegian municipalities” (the SKO-study). The SKO-study is a longitudinal study that examines employee well-being, service collaboration and -quality by conducting employee surveys as well as user satisfaction surveys in different municipal health services for children and their families in Norway. One of the aims of the SKO-study is to examine how satisfied parents or caregivers are with the services the municipalities provide to children and families. The current study uses data from 
all user satisfaction surveys that were conducted at 46 health centres $0-5$ years old in 27 municipalities in whole Norway that participated in the SKO-study ${ }^{20,22 .}$

Participating CHC received the necessary materials including employee information letters about the SKO-study with recommendations or instructions about the practical execution of the user satisfaction surveys. It also included general information material for users such as posters in addition to prepared user envelopes containing the survey, an information letter, and a pre-paid envelope addressed to the university ${ }^{20}$. All parents or caregivers of children who were followed up by the CHC in 27 participating municipalities were asked to fill out a questionnaire on paper or online. Data collection took place between September 2015 to January 2020 in the different municipalities or services. A total of eleven municipalities had two or more health centres $0-5$ years old. In most cases, the health centres $0-5$ years old was part of a Family House, representing one of many health services for children and their families. Each data collection period lasted on average approximately five weeks per service. Of the 27 municipalities, 23 provided information about the response rate. The average response rate was $50 \%$ and varied from $22 \%$ to $92 \%$ between the municipalities. The total number of questionnaires that were distributed in the different services were about 2941 and 1654 users filled in the questionnaire (response rate $=50 \%$; Table 1 ).

This paper is based on a previously conducted master's thesis that examined parental satisfaction with the child health center for children $0-5$ years old in the 12 northernmost municipalities that participated in the SKO-study ${ }^{23}$.

\section{Ethical considerations}

It is not known that the questions used in the user survey lead to discomfort. The SKO-study was approved by NSD - Norwegian Centre for Research Data. Participants received the questionnaire together with an information letter that was in accordance to the recommendations from NSD- Norwegian Centre for Research Data. The information letter 
included information about the background of the survey, that study participation was voluntary and anonymous, and about how the collected data was handled.

\section{Instruments}

The questionnaire consisted of 52 questions in addition to a comment field and was available in Norwegian and English. The survey items were adapted from the National Knowledge Center for the Health Service (Kunnskapssenteret), a questionnaire developed by Vedeler ${ }^{24}$ in connection with a user survey of open kindergartens, and a digital tool, www.bedrekommune.no, developed by the Norwegian Association of Local and Regional Authorities (KS) and Kommuneforlaget.

Of the 52 questions the first three were used to identify the service (e.g., name of municipality). A total of 25 questions were theoretically grouped into five topics around 1) User participation, 2) Accessibility, 3) Public health nurse, 4) Information, and 5) Overall evaluation with the service. An exploratory factor analysis (principal components analysis with varimax rotation) was conducted and identified four factors that reproduced the four scales User participation, Accessibility, Public health nurse, and Information. We chose to keep the fifth scale "Overall evaluation with the service” because it consisted out of two questions that loaded relatively low and on multiple scales.

The scale User participation consisted of two items (e.g., “To what extent is the public health nurse receptive to your needs/ wishes?”), with a five-point rating scale ranging from (1) “Not at all” to (5) “To a very great extent”.

The scale Accessibility consisted of five items (e.g., “To what extent are you satisfied with the opening hours of the child healthcare clinic?”), with a five-point rating scale ranging from (1) “Not at all” to (5) “To a very great extent”. 
The scale Public health nurse consisted of eleven items (e.g., "When you visit the child healthcare centre, to what extent do you feel that you are met with courtesy and respect by the public health nurse?”), with a five-point rating scale ranging from (1) “Not at all” to (5) “To a very great extent”.

The scale Information consisted of five items (e.g., "To what extent are you satisfied with information about your child's development?”), with a five-point rating scale ranging from (1) "Not at all” to (5) "To a very great extent”.

The scale Overall evaluation with the service consisted of two general questions, that is “Overall, how dissatisfied or satisfied are you with the child healthcare centre?” answered on a five-point scale from (1) "Very dissatisfied” to (5) "Very satisfied” and “Overall, to what extent would you say that you receive the help you need from the child healthcare centre?” with a five-point rating scale ranging from (1) "Not at all” to (5) “To a very great extent”. There were also two questions about collaboration, that is "Has your child received help of other public services (e.g., pedagogic-psychological services, physiotherapist, child and adolescent mental health services, etc.)?” with the answer categories “yes” and "no” and a follow-up question, that is "If yes, to what extent are you satisfied with the child healthcare centre's cooperation with the relevant services?, answered on a five-point scale from (1) “Very dissatisfied” to (5) "Very satisfied”.

Finally, there were ten demographic questions asking about the participant's role related to the child (mother, father, other), gender (male, female), age (19 years or younger, 20-30 years, 31-40 years, 41-50 years, 51-60 years, 61 years or older), number of children in the household, the child's age (0-3 months, 4-8 months, 9-12 months, 13-23 months, 2-3 years, 45 years), marital status (married/ cohabiting or not), completed education (“primary and lower secondary school”, “upper secondary school”, “college/ university (1-3 year)”, or ” college/ 
university (4 years or longer)), mother tongue (Norwegian, other European language and nonEuropean language, as well as specification of mother tongue no. 1 and 2), and occupational status (“employed”, “on leave”, “in education”, “Unemployed, off sick, on disability allowance or rehabilitation”, or “Homemaker”).

\section{Statistical Analyses}

SPSS 26 was used to conduct the statistical analyses, which included frequency distributions for the different survey items, correlations between variables, and Cronbach’s alpha for survey scales. To improve the readability of the results of the frequency distributions, answer categories 1 and 2, and 4 and 5 were combined. In accordance to the guidelines from the European Federation of Psychologist' Associations ${ }^{25}$ Cronbach’s alpha values from .70 or above were considered adequate.

Hierarchical regression analysis was conducted to predict the user's overall evaluation with the service. There was no need for using a multilevel approach since the intraclass correlation coefficient was .02, indicating that only a small proportion of the variance was explained by the grouping variable (i.e., municipality). In a first step, selected demographic characteristics were entered to the model, that is role in relation to child (mother $=0$ and father $=1$ ), age of the caregiver, at least one child younger than 2 years $(0=$ No and $1=$ yes $)$, education of the caregiver $(0$ = lower education and $1=$ higher education) and language (Other than Norwegian $=0$ and Norwegian $=1$ ). In a second step, the four predictors, that is User participation, Accessibility, Public health nurse, and Information were added to the demographic characteristics.

\section{Results}

Among the users of the CHC who filled in a user survey were 1486 mothers (91\%) and 145 fathers (9\%; see Table 1 for an overview of demographic information). Most of the 
participants were aged 20-40 years ( $n=1534$; 94\%), accompanied children under the age of 2 years to the child health center ( $n=1379 ; 85 \%)$, and had a university degree $(n=1052 ; 64 \%)$.

\section{Satisfaction with the Child Health Centres}

Almost all users found that the information they receive at the child health center is easy to understand and that the public health nurse meets them with courtesy and respect (98\%, respectively; see Table 2). Also, almost all users state that the public health nurse shows consideration towards the child (97\%) and that the public health nurse cooperates well with them (96\%). Fewer users have asked the public health nurse for advice regarding the upbringing of the child (54\%), and only 64\% state that they could influence the support from the child health centre. When it comes to the overall evaluation of the child health care center 0-5 years old, however, over $90 \%$ are satisfied with the service and feel that they receive the help they need from the child health center.

\section{The User Satisfaction Scales}

The mean scores for the four user satisfaction scales is generally high, with the lowest score for User participation $(M=4.06$; $S D=0.77)$ and the highest score for the Overall evaluation with the service $(M=4.45 ; S D=0.59$; see Table 3$)$. Correlations for the demographic characteristics with each other and with the user satisfaction scales are overall small and partly not significant. The user satisfaction scales themselves correlate significantly and positively with each other. Cronbach’s alpha for the five scales ranged from .69 (User participation) to .89. (Public health nurse).

\section{Predicting the Overall Evaluation with the Service}

The results of the hierarchical regression analysis are presented in Table 4 . In step 1 the $\mathrm{R}^{2}$ was .01 and not significant. Fathers seem to be more satisfied with the service compared to mothers. In step 2 all four user satisfaction scales were significant. The $\mathrm{R}^{2}$ was .62 and 
significant. The model explained a total of $63 \%$ of the variance in the overall evaluation of the service.

\section{Cooperation with other Services}

A total of 1332 (81\%) answered that their child had not received help of other public services, while 312 (19\%) answered yes. Of those who had received help 12 (4\%) were dissatisfied, 44 (15\%) answered “Both/and”, and 248 (82\%) were satisfied with the child healthcare centre's cooperation with the relevant services.

\section{Discussion}

Child health centres 0-5 years old (CHC) are one of many health services that Norwegian municipalities have to offer to children and their families. Examining user satisfaction with the $\mathrm{CHC}$ is important as it provides knowledge about how the users perceive the service they receive and about possible areas that can be improved. This study is, to our knowledge, the first study that reports findings of user surveys conducted at multiple CHC in Norway.

As expected, it is far more mothers than fathers that visit the child health center in Norway. This might be related to the distribution of the parental leave. Mothers often take the longest leave, including unpaid leave, and will thus be the ones with the opportunity to accompany the child to most consultations ${ }^{26}$. Also, the finding that most users were between the age of 20 to 40 years is not surprising, since the average age of birth for mothers is 31 years and for fathers 34 years in Norway ${ }^{27}$.

The distribution of responses to the survey items shows that, overall, users are satisfied with the CHCs in Norway. This finding is also reflected in the overall assessment of the service. A total of $95 \%$ of the users were satisfied with the service and $91 \%$ feel that they receive the help they need from the child health center. The high overall satisfaction may indicate that the 
CHCs meets parents' expectations of the service ${ }^{12}$. The results are comparable to the findings from the open kindergarten study, where $96 \%$ of the users were satisfied with the service ${ }^{20}$.

When taking a closer look at the single user satisfaction scales, users were most satisfied with the public health nurse. This can indicate that the public health nurses are good at building relationships with the parents and manage good collaboration with them during the consultations. Sanders and Roach ${ }^{28}$ found that the relationship between the service user and the healthcare professional is of great importance to the user perception of the service quality. Relationship building is based on trust between the public health nurse and the parent. The parent's trust in the public health nurse will, among other things, be linked to their trust in the public health nurse's competence ${ }^{29}$. The high satisfaction with the public health nurse may be an indication that the parents feel safe with the competence of the public health nurse. This is essential for the professionals in order to provide help ${ }^{29}$.

Overall, there were three items in the survey that received more varied answers than the others. The question that got lowest agreements in the whole survey was related to if the users ask the public health nurse for advice regarding the upbringing of the child. The current findings are comparable with findings from the open kindergarten study ${ }^{20}$. It might, on the other hand, indicate a lack of trust in the competence of the public health nurse or, more likely, that users are used to use other sources to look for health related information such as the internet or family and friends ${ }^{24}$. This may be because these sources are more accessible in everyday life. A lack of trust in the competence of the public health nurses at the CHCs would also be reflected in the other questions (i.e., "trust in advice regarding child's health and development" and "trust to detect whether child is not developing normally"). However, around $90 \%$ are satisfied with those two questions. A meta-analysis found that trust in health care professionals was related to subjective health outcomes and patient satisfaction ${ }^{30}$. 
The second question with more varied answers was part of the User participation scale. A total of $64 \%$ answered that they could influence the support from the child health center to a great extent, $25 \%$ stated to some extent, and $11 \%$ not at all. This result may be linked to the child health centre's guidelines that regulate the public health nurses in which type of examination they have to or can provide ${ }^{3}$. However, there might be more possibilities for public health nurses to include parents in the consultations and in the decisions about further follow-ups of them and the child that might be worth to examine.

The third question with more varied answers was part of the Information scale. The question to what extends users can find information they need regarding the $\mathrm{CHC}$ on for example the internet or in information brochures, answered 5\% not at all, $21 \%$ to some extent, and $74 \%$ to a great extent. To improve the quality of the service it would therefore be beneficial for each child health center to examine what can be done to improve so that users find the relevant and sufficient information easier.

Another aim of the study was to identify predictors of the overall evaluation with the CHC. All four user satisfaction scales were significant, and the strongest relationship was found for Public health nurse followed by Information, User participation, and Accessibility. This underlines once more the importance of the public health nurse that work at CHC. Satisfaction with the staff was also found to be the strongest predictor for the overall satisfaction with the open kindergarten ${ }^{20}$.

\section{Limitations}

The current paper used a cross-sectional design and it is not possible to make causal conclusions regarding the predictors of parent satisfaction ${ }^{31}$. The study is based on a questionnaire and the average response rate was $50 \%$, which is relatively high compared to other response rates in user surveys conducted in mental health care, who report rates between $23 \%$ to $38 \%{ }^{32}$. Another limitation is related to how the participants were recruited to the 
study. The questionnaire was distributed during the consultations at the $\mathrm{CHC}$, and thus we didn't get answers from those who didn't use the service in the period when the study was conducted or from those who do not visit the CHC at all. The latter one might constitute a more vulnerable group that may for various reasons be cause for concern ${ }^{33}$. This may constitute a group who may be less satisfied with the CHC. Even though the CHC has a high degree of coverage some consultations lack a higher percentage of attendance ${ }^{33}$. For example, in 2018 it were 5\% who did not attend to the four-year check-up compared to the $99 \%$ who attended to the eight-week consultation. However, there were no indications that those who did not attend the check ups constitute a special group ${ }^{33}$.

Cronbach's alpha for the different scales was adequate to good, except for the scale User participation which was slightly below the cut-off of $.70^{25}$. However, this scale consisted of two items only and its exclusion form the analysis would not have changed the conclusions. The average response rate was $50 \%$, which is in accordance to a weighted average response rate found in a meta-analysis of survey responses ${ }^{34}$. In the current study, more participants had completed higher education (64\%) compared to lower education (36\%). In the general Norwegian population, 62\% have lower education and 35\% higher education ${ }^{35}$. However, education was not a significant predictor in the regression analysis indicating that there is no difference in the overall evaluation between service user with lower and higher education. Furthermore, there was a bias regarding the sex of the respondents as $91 \%$ of the users who filled in the questionnaire were women. However, this was expected as it might be related to the distribution of the parental leave between mothers and fathers in Norway. Regarding the responses themselves, there was a ceiling effect, which makes it difficult to differentiated between individuals. 


\section{Conclusion}

In Norway, all children are entitled to receive regular health check-ups and most families are users of this service. The consultations children and their families receive at the CHC are regulated according to national guidelines. This study highlights important factors for maintaining satisfaction among users of CHC. Focus should be put on the public health nurse as they are the main professional that the children and families interact with during the consultations at the CHC. Leaders of CHC can use the public health nurse as a resource in the process of service improvement. Overall, the parents indicated a high degree of satisfaction with the service and in particular with the public health nurse. The findings also indicated room for improving the services, for example in terms of improving the information provided online, and also by facilitating user participation in terms of possibilities for the parents to influence the support provided.

\section{Funding}

The study was funded by UiT The Arctic University of Norway and the Norwegian Directorate of Health.

\section{Declaration of Conflicting Interests}

The authors declare that there is no conflict of interest

\section{Data Availability Statement}

Participants of this study did not agree for their data to be shared publicly, so supporting data is not available.

\section{Authors Contributions}

MM and SK designed the study; KJ and MBH helped with the data acquisition and the recrution of the municipalities, and SK and CCL conducted the analysis and interpreted the 
results. SK and CCL drafted the article and MM, KJ, and MBH revised it critically. All authors approved the final version of the manuscript.

\section{References}

1. Norwegian Ministry of Health and Care Services. Lov om kommunale helse- og omsorgstjenester m.m. [Municipal Health and Care Services Act]. LOV-2011-06-24-30. 2. Norwegian Ministry of Health and Care Services. Forskrift om kommunens helsefremmende og forebyggende arbeid i helsestasjons- og skolehelsetjenesten [Regulations on the municipality's health promotion and preventive work in the health and school health services]. FOR-2003-04-03-450.

3. Norwegian Directorate of Health. Helsestasjonsprogrammet: Alle barn 0-5 år bør få tilbud om regelmessige konsultasjoner på helsestasjonen [The health station program: All children $0-5$ years should be offered regular consultations at the health station], 


\section{https://www.helsedirektoratet.no/retningslinjer/helsestasjons-og-}

skolehelsetjenesten/helsestasjon-05-ar/helsestasjonsprogrammet-alle-barn-05-ar-bor-fa-tilbudom-regelmessige-konsultasjoner-pa-helsestasjonen (2021, Mars 04.).

4. utdanning.no. Yrkesbeskrivelse Helsesykepleier [Career description Health nurse], https://utdanning.no/yrker/beskrivelse/helsesykepleier (2021, May 21.).

5. Norwegian Ministry of Education and Research. Lov om barnehager (barnehageloven) [Law on kindergartens (Kindergarten law)]. LOV-2005-06-17-64.

6. Norwegian Ministry of Education and Research. Lov om grunnskolen og den vidaregåande opplæringa (opplæringslova) [Law on primary and secondary education (education law)]. LOV-1998-07-17-61.

7. Norwegian Ministry of Children and Equality. Lov om barneverntjenester (barnevernloven) [Child Welfare Services Act (Child Welfare Act)]. LOV-1992-07-17-100.

8. Martinussen M, Hansen MB and Adolfsen F. Familiens hus - organisering, samhandling og faglige perspektiver (2 utg.) [The family's house - organization, interaction and professional perspectives (2nd ed.)]. Regional Center for Child and Youth Mental Health - North, 2019.

9. Norwegian Directorate for Health and Social Affairs. Nasjonal strategi for kvalitetsforbedring i sosial- og helsetjenesten ...Og bedre skal det bli! (2005-2015) [National strategy for quality improvement in the social and health services ... And better it will be! (2005-2015)]. 2005. Oslo, Norway.

10. Norwegian Ministry of Health and Care Services. Forskrift om ledelse og kvalitetsforbedring i helse- og omsorgstjenesten [Regulations on management and quality improvement in the health and care service]. 2017.

11. Norwegian Ministry of Health and Care Services. Meld. St. 10, Melding til Stortinget, God kvalitet - trygge tjenester. Kvalitet og pasientsikkerhet i helse- og omsorgstjenesten 
[Meld. St. 10, Message to the Parliament, Good quality - Safe services. Quality and patient safety in health and care services]. 2012.

12. Grönroos C. A service quality model and its marketing implications. European Journal of Marketing 1984; 18: 36-44. DOI: 10.1108/EUM0000000004784.

13. Garratt AM, Bjertnaes OA, Holmboe O, et al. Parent experiences questionnaire for outpatient child and adolescent mental health services (PEQ-CAMHS Outpatients): reliability and validity following a national survey. Child Adolesc Psychiatry Ment Health 2011; 5: 18. 2011/05/24. DOI: 10.1186/1753-2000-5-18.

14. Rey JM, O'Brien M and Walter G. Is the satisfied customer one who also 'does well'? The relationship between outcome and parent satisfaction in a child and adolescent mental health service. Australasian Psychiatry 2002; 10: 246-249. DOI: 10.1046/j.14401665.2002.00485.x.

15. Kaplan S, Busner J, Chibnall J, et al. Consumer satisfaction at a child and adolescent state psychiatric hospital. Psychiatr Serv 2001; 52: 202-206. 2001/02/07. DOI: 10.1176/appi.ps.52.2.202.

16. Lambert W, Salzer MS and Bickman L. Clinical outcome, consumer satisfaction, and ad hoc ratings of improvement in children's mental health. J Consult Clin Psychol 1998; 66: 270-279. 1998/05/16. DOI: 10.1037//0022-006x.66.2.270.

17. Farzianpour F, Byravan R and Amirian S. Evaluation of Patient Satisfaction and Factors Affecting It: A Review of the Literature. Health 2015; 7: 1460-1465. DOI: 10.4236/health.2015.711160.

18. González IB, Pedraza Melo NA, Lavín Verástegui J, et al. Service quality and users satisfaction assessment in the health context in Mexico. Cuadernos de Administración (Universidad del Valle) 2017; 33: 36-47. 
19. Karaca A and Durna Z. Patient satisfaction with the quality of nursing care. Nursing Open 2019; 6: 535-545. DOI: 10.1002/nop2.237.

20. Kaiser S, Skjesol I, Sætrum A, et al. Parent satisfaction with the open kindergarten in Norway. International Journal of Health Promotion and Education 2020: 1-14. DOI: 10.1080/14635240.2020.1775674.

21. von Elm E, Altman DG, Egger M, et al. The Strengthening the Reporting of Observational Studies in Epidemiology (STROBE) statement: guidelines for reporting observational studies. PLoS Med 2007; 4: e296. 2007/10/19. DOI:

10.1371/journal.pmed.0040296.

22. Kaiser S, Patras J, Adolfsen F, et al. Using the Job Demands-Resources Model to evaluate work-related outcomes among Norwegian health care workers. SAGE Open 2020; 10: 2158244020947436. DOI: 10.1177/2158244020947436.

23. Lillevik CC. Foreldres tilfredshet med helsestasjon for barn 0-5 år [Parental satisfaction with the health center for children 0-5 years old]. Unpublished Master's thesis: UiT The Arctic University of Norway, 2020.

24. Vedeler GW. Åpen barnehage i Familiens hus - en brukerundersøkelse blant foreldre [Open kindergarten in the Family's house - a user satisfaction survey among parents]. Unpublished Master's thesis: University of Tromsø, Norway, 2009.

25. European Federation of Psychologist' Associations. EFPA Review model for the description and evaluation of psychological and educational tests: Test review form and notes for reviewers, v 4.2.6. 2013. EFPA.

26. Brandth B and Kvande E. Workplace support of fathers' parental leave use in Norway. Community, Work \& Family 2019; 22: 43-57. DOI: 10.1080/13668803.2018.1472067.

27. Statistics Norway. Født [Births], https://www.ssb.no/en/statbank/table/05530/ (2020, Mars 05). 
28. Sanders R and Roach G. Closing the gap? The effectiveness of referred access family support services. Child \& Family Social Work 2007; 12: 161-171. DOI:

\section{https://doi.org/10.1111/j.1365-2206.2006.00455.x.}

29. Grimen H. Profesjon og tillit [Profession and trust]. In: Molander IA and Terum LI (eds) Profesjonsstudier [Professional studies]. Oslo: Universitetsforlaget, 2008, pp.197-215.

30. Birkhauer J, Gaab J, Kossowsky J, et al. Trust in the health care professional and health outcome: A meta-analysis. PLoS One 2017; 12: e0170988. 2017/02/09. DOI: 10.1371/journal.pone.0170988.

31. Kesmodel US. Cross-sectional studies - what are they good for? Acta Obstetricia et Gynecologica Scandinavica 2018; 97: 388-393. DOI: https://doi.org/10.1111/aogs.13331. 32. Bjertnaes ØA, Garratt A and Johannessen JO. Innsamlingsmåte og resultater i brukerundersøkelser i psykisk helsevern. Tidsskrift for den Norske laegeforening 2006; 126: $1481-1483$.

33. Norwegian Directorate of Health. Manglende oppmøte på helsestasjon - En kartlegging rundt uteblivelse fra konsultasjoner i helsestasjonsprogrammet 0-5 år [Nonattendance at the health station - A survey of absences from consultations in the health station program 0-5 years]

2020.

34. Van Horn PS, Green KE and Martinussen M. Survey response rates and survey administration in counseling and clinical psychology: a meta-analysis. Educational and Psychological Measurement 2009; 69: 389-403. DOI: 10.1177/0013164408324462.

35. Statistics Norway. Befolkningens utadnningsnivå [Educational attainment of the population], https://www.ssb.no/en/utdanning/statistikker/utniv (2020, Mars 05). 
Table 1

Characteristics of the Study Sample $(N=1640-1644)$

\begin{tabular}{lcc}
\hline & $N$ & $\%$ \\
\hline Caregivers relationship to the child & \\
Mother & 1486 & 91 \\
Father & 145 & 9 \\
Other & 9 & 1
\end{tabular}

Age of the caregiver

$\begin{array}{lcc}\leq 19 \text { years } & 9 & 1 \\ 20-30 \text { years } & 754 & 46 \\ 31-40 \text { years } & 780 & 48 \\ 41-50 \text { years } & 93 & 6 \\ 51-60 \text { years } & 5 & 0.3 \\ \geq 61 \text { years } & 1 & 0.1\end{array}$

\section{Children's age}

0-3 months

$328 \quad 20$

4-8 months

$450 \quad 28$

9-12 months

$241 \quad 15$

13-23 months

$360 \quad 22$

2-3 years

$385 \quad 24$

4-5 years

$323 \quad 20$

Highest completed level of education

Primary and lower secondary school $59 \quad 4$

Upper secondary school $530 \quad 32$

College/ university (1-3 years)

College/ university ( $\geq 4$ years)

$548 \quad 33$

What is your native language?

Norwegian

$1460 \quad 89$

Another European language

$128 \quad 8$ 
Table 2

Frequency Distribution of Responses to Survey Items by User Satisfaction Scales

To a great

extent/ To a

$\begin{array}{lllll} & \text { Min- } & & \text { Not at all/To a } & \text { To some } \\ \text { very great } & \text { max } & M & S D \quad \text { minor extent } \quad \text { extent }\end{array}$

User participation $(N=1618-1636)$

receptive to needs

$1-5$

influence support from centre

$3.78 \quad 1.03$

$1 \%$

$8 \%$

$90 \%$

Accessibility $(N=1632-1637)$

getting contact with centre via telephone, e-mail, etc.

$\begin{array}{llllll}1-5 & 4.35 & 0.74 & 1 \% & 11 \% & 88 \% \\ 1-5 & 4.25 & 0.77 & 2 \% & 13 \% & 85 \% \\ 1-5 & 4.25 & 0.92 & 5 \% & 13 \% & 82 \% \\ 1-5 & 4.53 & 0.63 & 1 \% & 5 \% & 95 \% \\ 1-5 & 4.34 & 0.70 & 1 \% & 9 \% & 90 \%\end{array}$

appointments outside fixed consultations

physical accessibility (e.g., stairs, lift, etc.)

time set aside for consultation

opening hours

Public health nurse $(N=1633-1644)$

shows consideration toward you

understands your situation

$\begin{array}{llllll}1-5 & 4.45 & 0.68 & 1 \% & 6 \% & 93 \% \\ 1-5 & 4.43 & 0.69 & 1 \% & 7 \% & 92 \%\end{array}$


shows consideration towards your child

meets you with courtesy and respect

cooperates well with you

follows up on what you agreed

trust in advice regarding child's health and development

trust to detect whether child is not developing normally

meet the same nurse

you can raise difficult subjects

ask for advice regarding upbringing of child

$\begin{array}{llllll}2-5 & 4.61 & 0.56 & 0.4 \% & 2 \% & 97 \% \\ 1-5 & 4.67 & 0.53 & 0.4 \% & 2 \% & 98 \% \\ 1-5 & 4.59 & 0.60 & 1 \% & 4 \% & 96 \% \\ 1-5 & 4.46 & 0.65 & 1 \% & 6 \% & 94 \% \\ 1-5 & 4.40 & 0.69 & 1 \% & 8 \% & 91 \% \\ 1-5 & 4.31 & 0.74 & 1 \% & 11 \% & 88 \% \\ 1-5 & 4.38 & 0.95 & 6 \% & 10 \% & 84 \% \\ 1-5 & 4.22 & 0.85 & 3 \% & 13 \% & 84 \% \\ 1-5 & 3.57 & 1.11 & 16 \% & 31 \% & 54 \%\end{array}$

(continued) 
Table 2 Frequency Distribution of Responses to Survey Items by User Satisfaction Scales (continued)

\begin{tabular}{|c|c|c|c|c|c|c|}
\hline & \multirow[b]{2}{*}{ Min- } & & & \multirow[b]{2}{*}{ Not at all/To a } & \multirow[b]{2}{*}{ To some } & $\begin{array}{l}\text { To a great } \\
\text { extent/ To a }\end{array}$ \\
\hline & & & & & & very great \\
\hline & $\max$ & $M$ & $S D$ & minor extent & extent & extent \\
\hline \multicolumn{7}{|l|}{ Information $(N=1613-1644)$} \\
\hline easy to understand & $2-5$ & 4.57 & 0.55 & $0.2 \%$ & $2 \%$ & $98 \%$ \\
\hline adequate & $1-5$ & 4.34 & 0.71 & $1 \%$ & $10 \%$ & $89 \%$ \\
\hline satisfied with information about child's development & $1-5$ & 4.38 & 0.71 & $1 \%$ & $9 \%$ & $90 \%$ \\
\hline find information you need regarding centre on the internet, etc, & $1-5$ & 4.01 & 0.87 & $5 \%$ & $21 \%$ & $74 \%$ \\
\hline Overall, the centre provides me with the information I need & $1-5$ & 4.39 & 0.66 & $1 \%$ & $6 \%$ & $93 \%$ \\
\hline \multicolumn{7}{|l|}{ Overall evaluation $(N=1640-1642)$} \\
\hline Overall, how dissatisfied or satisfied are you with the child health & $1-5$ & 4.55 & 0.64 & $1 \%$ & $4 \%$ & $95 \%$ \\
\hline centre $?^{1}$ & & & & & & \\
\hline Overall, to what extent would you say that you receive the help & $1-5$ & 4.36 & 0.68 & $1 \%$ & $7 \%$ & $91 \%$ \\
\hline
\end{tabular}

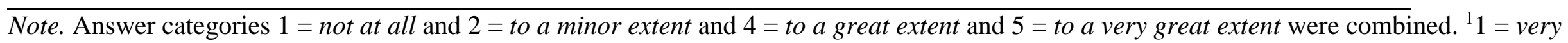
dissatisfied to 5 = very satisfied. 
Table 3

Descriptive Statistics ( $N=1609-1652)$

$M$

SD 1.

2.

3.

4.

5.

6.

7.

8.

9.

Demographic characteristics

1. Role in relation to child ${ }^{\mathrm{a}}$

2. Age caregiver

- $\quad-.20^{* * *}$

3. Child $<24$ months ${ }^{\mathrm{b}}$

4. Education ${ }^{\mathrm{c}}$

5. Norwegian language ${ }^{\mathrm{d}}$

$\begin{array}{llll}- & - & -.05 & -.17^{* * *}\end{array}$

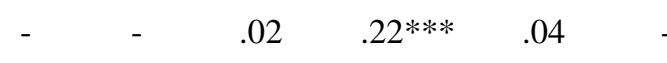

$\begin{array}{lllllll}- & - & .03 & -.07 * * & -.03 & -.05 * & -\end{array}$

User satisfaction scales

6. User participation

$\begin{array}{lllllllll}4.06 & 0.77 & -.02 & -.05 * & .07 * * & -.03 & -.00 & .69\end{array}$

7. Accessibility

$\begin{array}{lllllllll}4.35 & 0.55 & -.03 & -.07 * * & .05 * & -.02 & .01 & .50 * * * & .78\end{array}$

8. Public health nurse

$4.37 \quad 0.52 \quad-.03$

$\begin{array}{llllll}-.09^{* * *} & .08^{* *} & -.04 & -.01 & .71^{* * *} & .61^{* * *}\end{array}$

.89

9. Information

$\begin{array}{lll}4.34 & 0.57 \quad .00\end{array}$

10. Overall evaluation

$4.45 \quad 0.59 \quad .03$

$\begin{array}{llllllll}-.03 & .02 & -.05 * & -.02 & .60 * * * & .61 * * * & .73 * * * & .86\end{array}$

$\begin{array}{lllllllll}-.03 & .06 * & -.00 & .02 & .64 * * * & .54 * * * & .75 * * * & .68 * * * & .73\end{array}$

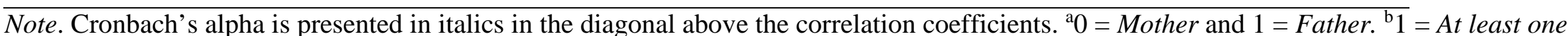

child younger than 24 months and $0=$ Child older than 24 months. ${ }^{\mathrm{c}} 0=$ Lower education and $1=$ Higher education. ${ }^{\mathrm{d}} 0=$ Other language than

Norwegian and $1=$ Norwegian language. ${ }^{*} p<.05 .{ }^{* *} p<.001 .{ }^{* * *} p<.001$ (two-tailed). 
Table 4

Hierarchical Regression Analysis Predicting the Overall Evaluation of the Service $(N=$ 1590)

\begin{tabular}{|c|c|}
\hline & $\begin{array}{c}\text { Overall } \\
\text { evaluation }\end{array}$ \\
\hline Variable & $\Delta R^{2}$ \\
\hline
\end{tabular}

\section{Demographic characteristics $\quad .01$}

Role in relation to child ${ }^{\mathrm{a}}$

Age caregiver

Child $<24$ months ${ }^{\mathrm{b}}$

High education $^{\mathrm{c}}$

Norwegian language $^{d}$

User satisfaction scales

User participation

Accesibility

Public health nurse

Information

$R^{2}$
$.03 *$

.01

.01

.02

.03

$.62 * * *$

$.04 *$

$.44^{* * *}$

$.25^{* * *}$

Note. ${ }^{\mathrm{a}} 0=$ Mother and $1=$ Father. ${ }^{\mathrm{b}} 1=$ At least one child younger than 24 months and $0=$ Child older than 24 months. ${ }^{\mathrm{c}} 0=$ Lower education and $1=$ Higher education. ${ }^{\mathrm{d}} 0=$ Other language than Norwegian and 1 = Norwegian language .

${ }^{*} p<.05 .{ }^{* * *} p<.001$. 